\title{
Fracture toughness and critical strain energy release rate of dental amalgam
}

\author{
J. C. ROBERTS, J. M. POWERS, R. G. CRAIG \\ The University of Michigan, School of Dentistry, Ann Arbor, Michigan 48109, USA
}

Fracture toughness, critical strain energy release rate and critical stress intensity factor were determined for lathe-cut, spherical, admixed, and two atomized high-copper dental amalgams. At a loading rate of $0.005 \mathrm{~cm} \mathrm{~min}^{-1}$ for 24 -hour samples, the spherical amalgam had the highest resistance to unstable crack propagation. At a loading rate of $0.05 \mathrm{~cm}$ $\mathrm{min}^{-1}$ for both 24-hour and one-month samples, the lathe-cut amalgam had the highest resistance to unstable crack propagation. One of the atomized high copper amalgams showed the lowest resistance to crack propagation. The values were consistent with data obtained in single-pass wear studies.

\section{Introduction}

The critical stress intensity factor describes the state of stress at the edges of a crack at the onset of fracture, while the critical strain energy release rate is a measure of the energy necessary for crack initiation. Irwin [1] derived the mathematical formulations of the critical stress intensity factor and the critical strain energy release rate from the experimental work of Griffith [2]. Gurney and Mai [3] developed an experimental technique for measurement of the energy necessary for crack propagation or fracture toughness. The work of Roberts et al. [4] showed a correlation between fracture toughness and single-pass wear data of commercial and experimental dental restorative resins and composites.

The purpose of this investigation was to measure the fracture toughness, critical strain energy release rate, and critical stress intensity factor for dental amalgam. These results were correlated with data obtained from single-pass wear studies of dental amalgam [5].

\section{Materials and methods}

The fracture toughness $(R)$, critical stress intensity factor $\left(K_{\mathrm{IC}}\right)$ and the critical strain energy release rate $\left(G_{\mathrm{IC}}\right)$ were determined at two loading rates for an admixed amalgam (A), a lathe-cut amalgam (B), a spherical amalgam (C) and two atomized high-copper amalgams (D and E). Product names, batch numbers, alloy compositions, mercuryalloy ratios and manufacturers are listed in Table I.

The amalgams were prepared according to the manufacturers' instructions and condensed into a rectangular hole $(20 \mathrm{~mm}$ long, $4 \mathrm{~mm}$ wide and $2.5 \mathrm{~mm}$ deep) in a four-piece rectangular die ( $38 \mathrm{~mm}$ long, $19 \mathrm{~mm}$ wide and $14 \mathrm{~mm}$ high). Prenotching of the specimens was accomplished by means of a spacer inserted into the die as shown in Fig. 1. The samples were stored at $37^{\circ} \mathrm{C}$ for both $24 \mathrm{~h}$ and one month before testing.

The specimens were loaded in three-point bending by a test fixture placed on a compression load cell in a testing machine. ${ }^{\dagger}$ The three-point bending fixture consisted of two stainless steel knife edges $(0.246 \mathrm{~mm}$ tip radius) that supported the specimen while being loaded from above by a cylindrical tapered rod $(0.246 \mathrm{~mm}$ tip radius $)$ as shown in Fig. 1. Loads were applied at cross-head rates of 0.005 and $0.05 \mathrm{~cm} \mathrm{~min}^{-1}$. The load and deflection data were taken from the chart recorder.

Load-defelection data were obtained for use in

\footnotetext{
*Now in the Department of Mechanical Engineering, Rensselaer Polytechnic Institute, Troy, New York 12181, USA.

$\dagger$ Model TT-BM, Instron Corporation, Canton, Mass. 02021.
} 
TABLE I Name, batch number, nominal alloy composition, mercury-alloy ratio and manufacturer of materials evaluated.

\begin{tabular}{|c|c|c|c|c|}
\hline Code & $\begin{array}{l}\text { Product name } \\
\text { and batch number }\end{array}$ & $\begin{array}{l}\text { Nominal alloy } \\
\text { composition (wt } \% \text { ) }\end{array}$ & $\begin{array}{l}\text { Mercury-alloy } \\
\text { ratio }\end{array}$ & Manufacturer \\
\hline A & $\begin{array}{l}\text { Dispersalloy } \\
\text { No. A4001 }\end{array}$ & $72 \% \mathrm{Ag}, 26 \% \mathrm{Sn}, 2 \% \mathrm{Cu}$ & 1.00 & $\begin{array}{l}\text { Johnson \& Johnson } \\
\text { East Windsor, NJ } 08520\end{array}$ \\
\hline B & $\begin{array}{l}\text { New True Dentalloy } \\
\text { No. } 3057306\end{array}$ & $72 \% \mathrm{Ag}, 26 \% \mathrm{Sn}, 2 \% \mathrm{Cu}$ & 1.20 & $\begin{array}{l}\text { S. S. White } \\
\text { Dental Products Div. } \\
\text { Philadelphia, PA } 10102\end{array}$ \\
\hline $\mathrm{C}$ & $\begin{array}{l}\text { Spheraloy } \\
\text { Spher-A-Caps } \\
\text { No. } 1028\end{array}$ & $72 \% \mathrm{Ag}, 26 \% \mathrm{Sn}, 2 \% \mathrm{Cu}$ & 0.93 & $\begin{array}{l}\text { Kerr Sybron Corp, } \\
\text { Romulus, MI } 48174\end{array}$ \\
\hline $\mathrm{D}$ & $\begin{array}{l}\text { Sybraloy } \\
\text { No. } 0410762096\end{array}$ & $40 \% \mathrm{Ag}, 30 \% \mathrm{Sn}, 30 \% \mathrm{Cu}$ & 0.85 & $\begin{array}{l}\text { Kerr Sybron Corp. } \\
\text { Romulus, MI } 48174\end{array}$ \\
\hline E & $\begin{array}{l}\text { Tytin } \\
\text { No. } 627606\end{array}$ & $60 \% \mathrm{Ag}, 27 \% \mathrm{Sn}, 13 \% \mathrm{Cu}$ & 0.77 & $\begin{array}{l}\text { S. S. White } \\
\text { Dental Products Div. } \\
\text { Philadelphia, PA } 10102\end{array}$ \\
\hline
\end{tabular}

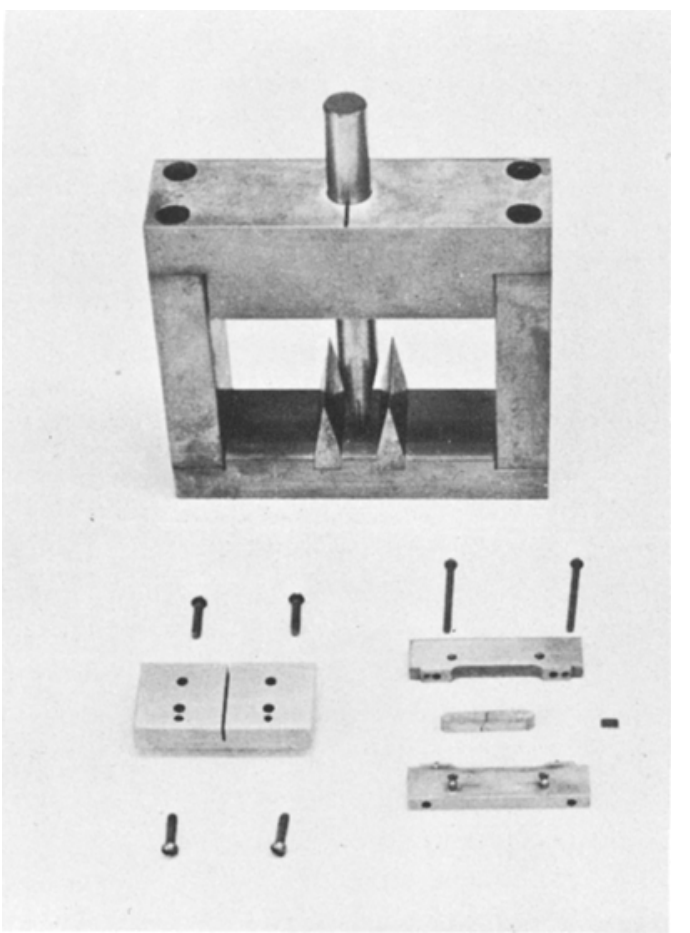

Figure 1 Fracture toughness test fixture and dies.

calculation of fracture toughness $(R)$ by the formula [6], $R=(P \delta / 2) /(B w-a B)$, where $P$ is load at failure, $\delta$ is deflection at failure, $B$ is specimen width, $w$ is specimen height, and $a$ is the notch length. The critical stress intensity factor $\left(K_{\text {IC }}\right)^{*}$ was calculated by the formula [7] ;

$$
\begin{aligned}
K_{\mathrm{IC}}= & \left\{(3 P L \sqrt{ } a) /\left(2 B w^{2}\right)\right\}\{1.93-3.07(a / w) \\
& +14.53(a / w)^{2}-25.11(a / w)^{3} \\
& \left.+25.80(a / w)^{4}\right\}
\end{aligned}
$$

where $P$ is the load at failure, $L$ is the length between knife edges, $a$ is the notch length, $w$ is the specimen height, and $B$ is the specimen width. The critical strain energy release rate $\left(G_{I C}\right)$ was calculated from the formula [8];

$$
G_{\mathrm{IC}}=K_{\mathrm{IC}}{ }^{2} / E,
$$

where $E$ is the modulus of elasticity $\dagger$. The modulus of elasticity and $0.1 \%$ yield strength of materials $\mathrm{A}$ to $\mathrm{E}$ were determined experimentally from three-point bending of unnotched specimens.

Five samples of each material were tested at the aforementioned cross-head rates. Mean values were compared by Scheffe intervals computed from the analysis of variance [9]. A scanning electron microscope $\$$ was used to study the fractured surfaces.

\section{Results}

Mean values of fracture toughness $(R)$ with Scheffé intervals obtained from a two-way analysis of variance are shown in Fig. 2 for the amalgams (A to $\mathrm{E}$ ) and a composite resin (F) [4] . Comparison of the means were made with Scheffé intervals of $39 \mathrm{Nm}^{-1}$ among materials, $16 \mathrm{Nm}^{-1}$ between loading rates and of $15 \mathrm{Nm}^{-1}$ between times at the

*For the ratio of length to thickness of about 4.

†T The plane stress computation for $G_{\mathrm{IC}}$ was used because dental amalgam does not behave like a high strength metal but rather like a viscoelastic material. If the plane strain computation were used [8], $G_{\mathrm{IC}}=K_{\mathrm{IC}}{ }^{2}\left(1-\nu^{2}\right) / E$, where $\nu$ is Poisson's ratio. In this study $\nu=0.33$; therefore, $\left(G_{\mathrm{IC}}\right)$ plane strain $=0.89\left(G_{\mathrm{IC}}\right)$ plane stress.

¥SMS-II, International Scientific Instruments, Mountain View, CA. 


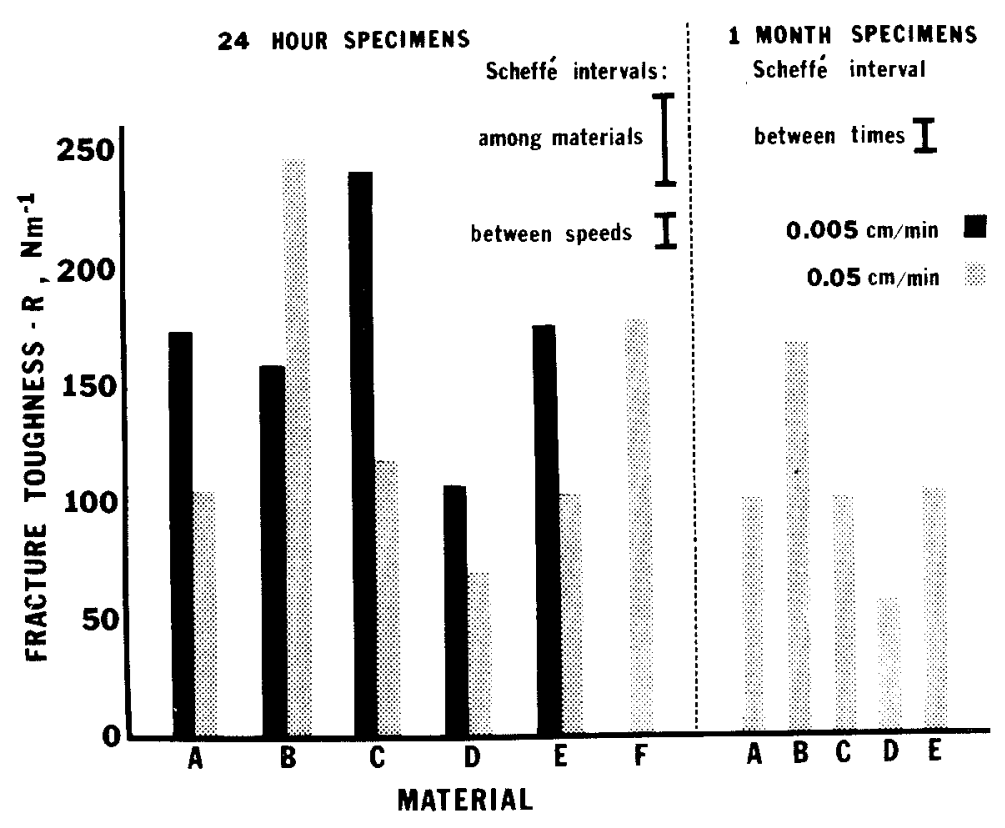

Figure 2 Fracture toughness for dental amalgams $\mathrm{A}$ to $\mathrm{E}$ and a dental composite resin $\mathrm{F}$ at loading rates of $0.005 \mathrm{~cm} \mathrm{~min}^{-1}$ and 0.05 $\mathrm{cm} \mathrm{min}^{-1}$, and after $24 \mathrm{~h}$ and one month.

95\% level of confidence. At a loading rate of $0.005 \mathrm{~cm} \mathrm{~min}^{-1}$ there were no significant differences between materials $\mathrm{A}, \mathrm{B}$ and $\mathrm{E}$. At a loading rate of $0.05 \mathrm{~cm} \mathrm{~min}^{-1}$ there were no significant differences between materials $A, D$ and $E$ nor between materials $\mathrm{A}, \mathrm{C}$ and $\mathrm{E}$. There were significant differences between loading rates for materials A through $\mathrm{E}$. There were no significant differences between the 24-hour and one-month tests for materials A, C, D and E. Material C, the spherical amalgam, had the highest value of $R$ at a loading rate of $0.005 \mathrm{~cm} \mathrm{~min}^{-1}$. Material $B$, the lathe-cut amalgam, had the highest value of $R$ at a loading rate of $0.05 \mathrm{~cm} \mathrm{~min}^{-1}$. At both loading rates material $\mathrm{D}$ had the lowest value of $R$. For material $\mathrm{B}, R$ decreased signifantly when the one-month samples were compared with the 24-hour samples.

Fig. 3 shows mean values and Scheffe intervals of critical strain energy release rate $\left(G_{\mathrm{IC}}\right)$. The means with Scheffé intervals were computed from a two-way analysis of variance. A comparison of the means were made with Scheffe intervals of
Figure 3 Critical strain energy release rate for dental amalgams $A$ to $E$ at loading rates of $0.005 \mathrm{~cm}$ $\min ^{-1}$, and after $24 \mathrm{~h}$ and one month.

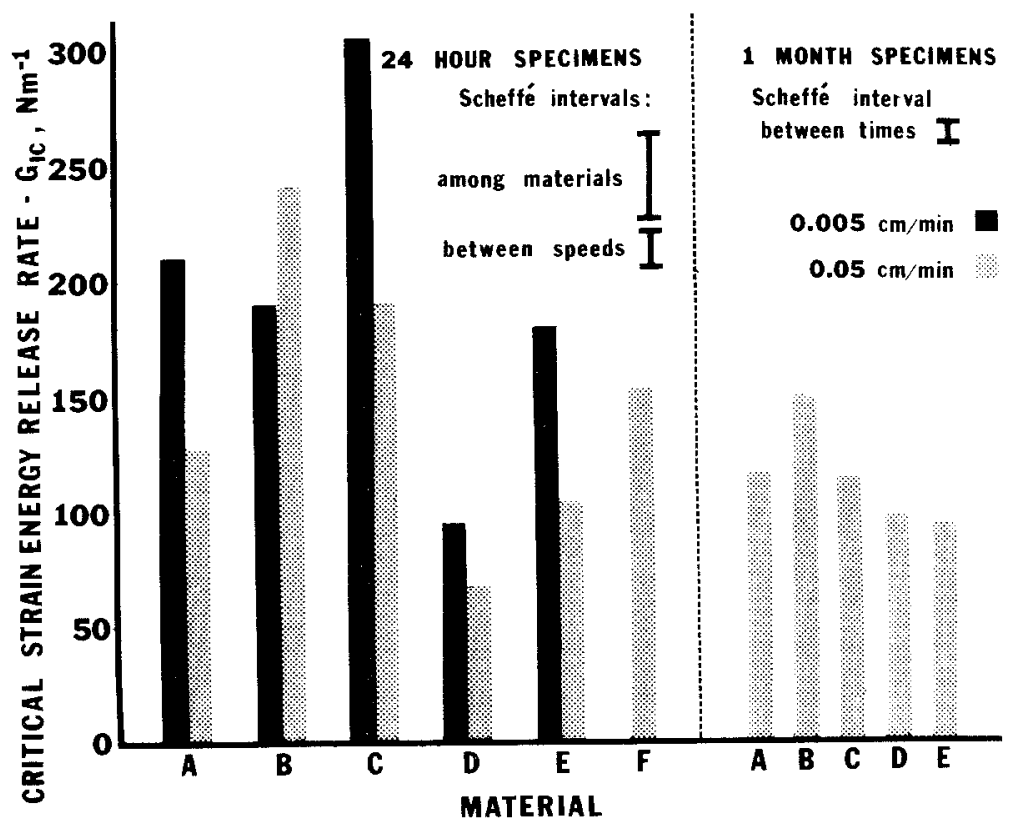




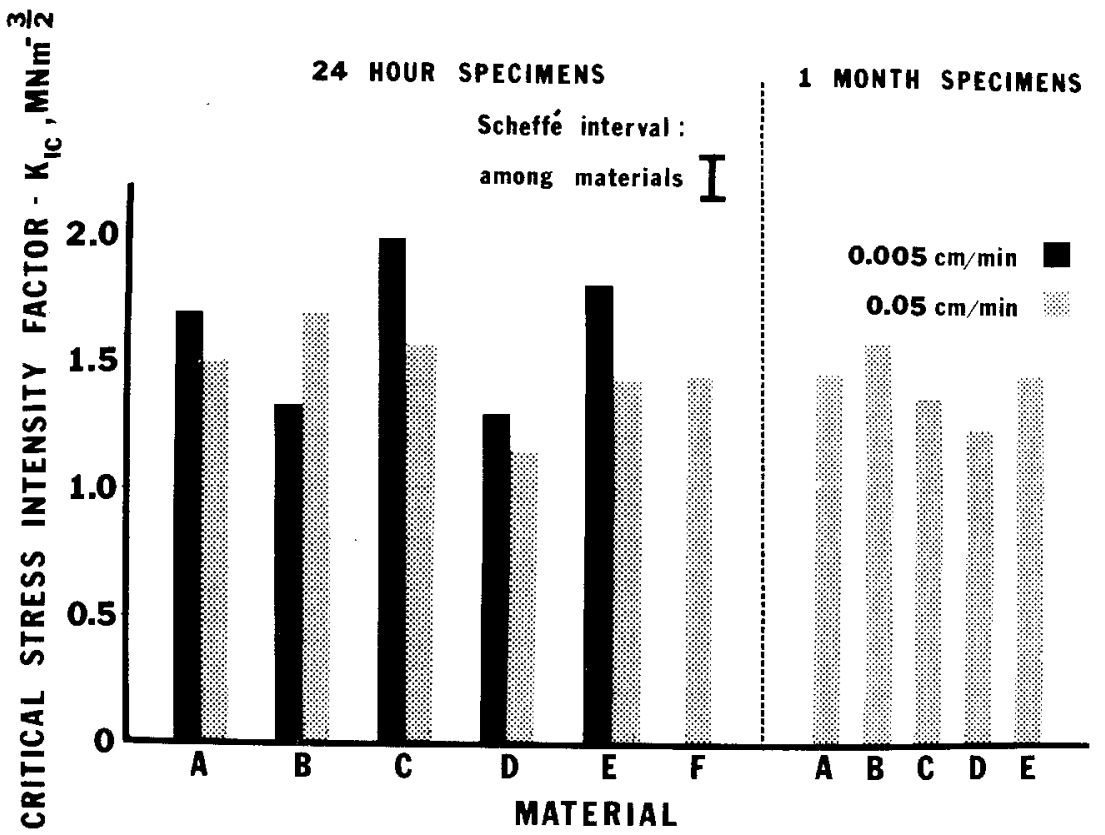

Figure 4 Critical stress intensity factor for dental amalgams $A$ to $E$ at loading rates of $0.005 \mathrm{~cm} \mathrm{~min}^{-1}$ and $0.05 \mathrm{~cm} \mathrm{~min}^{-1}$, and after $24 \mathrm{~h}$ and one month.

$39 \mathrm{Nm}^{-1}$ among materials, $17 \mathrm{Nm}^{-1}$ between loading rates, and of $12 \mathrm{Nm}^{-1}$ between times at the $95 \%$ level of confidence. At a loading rate of $0.005 \mathrm{~cm} \mathrm{~min}^{-1}$, there were no significant differences between materials A, B, and E. At a loading rate of $0.05 \mathrm{~cm} \mathrm{~min}^{-1}$, there were no significant differences between materials $\mathrm{D}$ and $\mathrm{E}$ nor between $\mathrm{A}$ and $\mathrm{E}$. There was no significant difference between loading rates for material $D$. There were no signifant differences between times for materials $\mathrm{A}$ and $\mathrm{E}$. Material $\mathrm{C}$ had the highest value of $G_{\text {IC }}$ at a loading rate of $0.005 \mathrm{~cm} \mathrm{~min}^{-1}$, while material B had the highest value of $G_{I C}$ at a loading rate of $0.05 \mathrm{~cm} \mathrm{~min}^{-1}$. Material $D$ had the lowest value of $G_{\mathrm{IC}}$ at both loading rates. $G_{\mathrm{IC}}$ for materials $\mathrm{B}$ and $\mathrm{C}$ decreased and for $\mathrm{D}$ increased significantly when one-month samples were compared with the 24-hour samples.

$R$ of the diacrylate resin with inorganic filler (F) was higher than values for the admixed amalgam (A), the spherical amalgam (C) and the two atomized high-copper amalgams (D and E), but lower than values for the lath-cut amalgam (B).

The means with Scheffe intervals for the critical stress intensity factor $\left(K_{\mathrm{IC}}\right)$ are shown in Fig. 4. A comparison of the means were made with Scheffé intervals among materials of $0.19 \mathrm{MNm}^{-3 / 2}$ at the 95\% level of confidence. At a loading rate of $0.005 \mathrm{~cm} \mathrm{~min}^{-1}$, there were no significant differences between materials $B$ and $D, A$ and $E$ nor $C$ and $E$. At a loading rate of $0.05 \mathrm{~cm} \mathrm{~min}^{-1}$, there were no significant differences between materials

TABLE II Modulus of elasticity and yield strength of dental amalgam from three-point bending at two times and loading rates.

\begin{tabular}{|c|c|c|c|c|c|c|c|}
\hline \multirow[t]{3}{*}{ Code } & \multirow[t]{3}{*}{ Material } & \multicolumn{4}{|l|}{ 24-hour* } & \multirow{2}{*}{\multicolumn{2}{|c|}{$\frac{\text { One-month }^{*}}{0.05 \mathrm{~cm} \mathrm{~min}^{-1}}$}} \\
\hline & & \multicolumn{2}{|l|}{$0.005 \mathrm{~cm} \mathrm{~min}^{-1}$} & \multicolumn{2}{|l|}{$0.05 \mathrm{~cm} \mathrm{~min}^{-1}$} & & \\
\hline & & $\begin{array}{l}\text { Modulus } \\
(\mathrm{MPa})\end{array}$ & $\begin{array}{l}\text { Yield strength } \\
(\mathrm{MPa})\end{array}$ & $\begin{array}{l}\text { Modulus } \\
\text { (MPa) }\end{array}$ & $\begin{array}{l}\text { Yield strength } \\
(\mathrm{MPa})\end{array}$ & $\begin{array}{l}\text { Modulus } \\
\text { (MPa) }\end{array}$ & $\begin{array}{l}\text { Yield strength } \\
(\mathrm{MPa})\end{array}$ \\
\hline A & Dispersalloy & $13000(3000)$ & $124(17)$ & $17700(2050)$ & 130)21) & $18500(2100)$ & $176(27)$ \\
\hline B & $\begin{array}{l}\text { New true } \\
\text { dentalloy }\end{array}$ & $9000(800)$ & $67(15)$ & $12800(2800)$ & $119(25)$ & $16600(3100)$ & $140(32)$ \\
\hline $\mathrm{C}$ & Spheraloy & $13000(3000)$ & $91(13)$ & $12900(2900)$ & $142(22)$ & $16500(3200)$ & $160(17)$ \\
\hline $\mathrm{D}$ & Sybraloy & $18000(1000)$ & $122(20)$ & $19800(2500)$ & $141(40)$ & $15800(5500)$ & $98(60)$ \\
\hline $\mathrm{E}$ & Tytin & $18000(3000)$ & $163(14)$ & $20100(1600)$ & $163(23)$ & $21900(2100)$ & $200(35)$ \\
\hline
\end{tabular}

\footnotetext{
* Means with standard deviations in parentheses were determined from five replications.
} 
$A, C$ and $E$ nor between $A, B$ and C. Material D had the lowest value of $K_{\text {IC }}$ at both loading rates. There were no significant differences in $K_{\text {IC }}$ between 24-hour and one-month samples nor between loading rates for materials A to E. $K_{\text {IC }}$ of the diacrylate resin with inorganic filler $(F)$ was about the same as that for the amalgams (A to E).

Scanning electron photomicrographs of the fracture surfaces of materials $A$ to $E$ at a loading rate of $0.05 \mathrm{~cm} \mathrm{~min}^{-1}$ are shown in Fig. 5. Mean values with standard deviation of modulus of elasticity and yield strength in bending are presented in Table II.

\section{Discussion}

The testing of fracture toughness of materials A to $E$ under conditions of three-point bending resulted in unstable crack propagation. An unstable crack cannot be arrested and no energy beyond the initial energy is required to keep it propagating. Thus, the fracture toughness $(R)$ becomes a measure of the energy required to propagate an unstable crack and should be the same as the critical strain energy release rate $\left(G_{I C}\right)$.
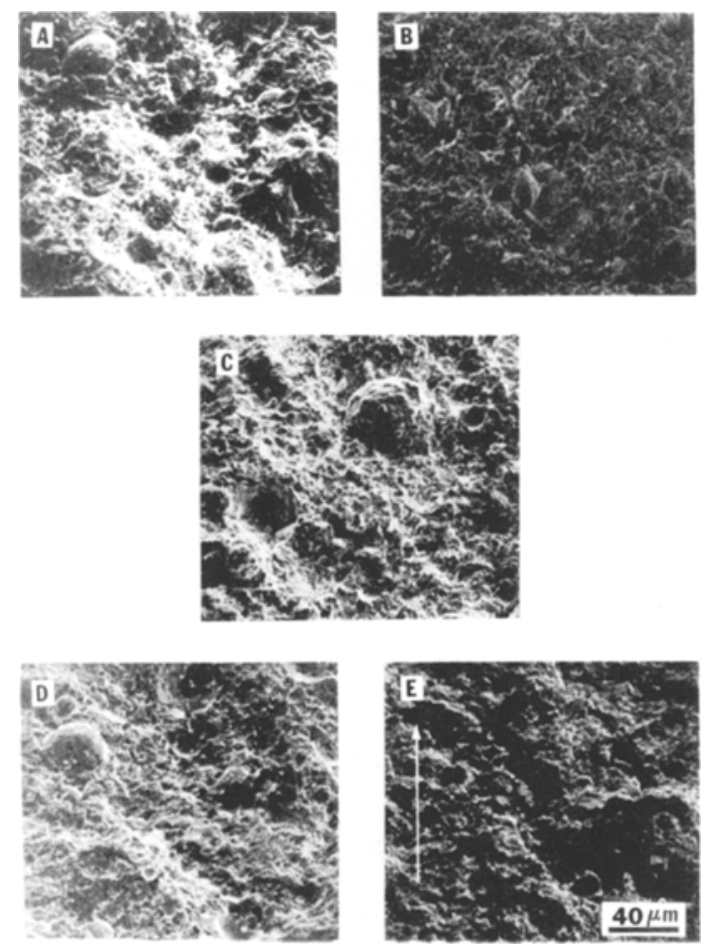

Figure 5 Scanning electron photomicrograph of fracture surfaces of dental amalgams $A$ to $E$ at a loading rate of $0.05 \mathrm{~cm} \mathrm{~min}^{-1}$. The arrow in $\mathrm{E}$ indicates the direction of crack propagation.
The correlation coefficient $(r)$ for $R$ versus $G_{\text {IC }}$ for materials A to E at both times and loading rates was computed [9] to be 0.907 . The critical value of $r$ above which the hypothesis of independence of $R$ and $G_{\text {IC }}$ could be rejected was 0.514 at the $95 \%$ level of confidence. The correlation between the experimental technique for the measurement of $R$ developed by Gurney and Mai [3] and the theoretical technique for the calculation of $G_{\text {IC }}$ from linear elastic fracture mechanics [1] was confirmed even though amalgam has been found to exhibit viscoelastic behaviour [10].

The spherical amalgam (C) had higher values of $R$ and $G_{\mathrm{IC}}$ than the other materials at a loading rate of $0.005 \mathrm{~cm} \mathrm{~min}^{-1}$. However, at a loading rate of $0.05 \mathrm{~cm} \mathrm{~min}^{-1}$, the lathe-cut amalgam (B) had higher values of $R$ and $G_{\text {IC }}$ than the other materials The atomized high-copper amalgam with the lowest wt \% silver and highest wt \% copper (D) had the lowest values of $R$ and $G_{\mathrm{IC}}$ at both loading rates. The admixed amalgam (A) and the spherical amalgam (C) had the same values of $R$ and $G_{\mathrm{IC}}$ in the one-month test. Therefore, the resistance to unstable crack propagation in amalgam appears to be dependent on the phases present, the amount, size, and shape of these phases, and their relative strengths.

The mean value of $R$ decreased by about $4,32,14,16$, and $4 \%$ for materials $A$ to $E$, respectively, when one-month samples were compared to 24-hour samples. Apparently, the phase change in material $\mathrm{A}$, the admixed amalgam, between 24 hours and one month, eliminating the weaker $\mathrm{Sn}_{7} \mathrm{Hg}$ phase [11], did not significantly affect the fracture toughness. The longer setting time of the lathe-cut amalgam (B) [12] may account for the large decrease in $R$ for this material.

The critical stress intensity factor $\left(K_{\text {IC }}\right)$ describes the state of stress around the unstable crack. $K_{\mathrm{IC}}$ is an indication of the stress required to produce castastrophic propagation of a crack. At a loading rate of $0.005 \mathrm{~cm} \mathrm{~min}^{-1}$, material $\mathrm{C}$, the spherical amalgam, was least sensitive to unstable cracks, while material $\mathrm{B}$, the lathe-cut amalgam, was least sensitive to unstable cracks, at a loading rate of $0.05 \mathrm{~cm} \mathrm{~min}^{-1}$. Material $\mathrm{D}$ was the most sensitive to unstable cracks at both loading rates. $K_{\text {IC }}$ is affected by many factors; however, the presence of the unreacted alloy particles may influence the sensitivity of the material to unstable 
crack propagation, just as the presence of filler particles does in the filled diacrylate resins [4]. There was at most only a $12 \%$ difference in sensitivity to unstable cracks when the 24-hour samples were compared with the one-month samples for materials $\mathrm{A}$ to $\mathrm{E}$.

In the 24-hour test, the modulus of elasticity and yield strength were highest for material $\mathrm{E}$ and lowest for material B, at both loading rates. However, in the one-month test the modulus of esasticity and yield strength were highest for material E but lowest for material $D$. The values of modulus of elasticity in three-point bending were 30 to $50 \%$ lower than values of apparent modulus of elasticity measured in compression by Powers and Farah [13]. The correlation coefficients $(r)$ for $R$ and $G_{\text {IC }}$ versus modulus of elasticity for material $A$ through $E$ at both times and loading rates were computed [9] to be -0.553 and -0.725 , respectively. The critical value of $r$ above which the hypothesis of independence of $R$ and $G_{\text {IC }}$ with the modulus of elasticity could be rejected was 0.514 at the $95 \%$ confidence level. The correlation coefficients for $R$ and $G_{\text {IC }}$ versus yield strength for materials $A$ through $E$ at both times and loading rates were computed [9] to be -0.348 and -0.486 , respectively. The critical value of $r$ of 0.514 indicates that no correlation existed between $R$ or $G_{\mathrm{IC}}$ and yield strength.

The fracture surfaces of all amalgams tested were rough and gave no indication as to the direction of crack propagation. The roughness resulted from "pull-out" of the unreacted alloy particles. The fractured surfaces of materials A to $E$ appeared to be the result of ductile failure, as shown in Fig. 5. All materials failed by unstable crack propagation and there was no change in crack velocity. The appearance of the fracture amalgam surface was dull and rough with no indication as to the direction of crack propagation. There was no transition from a ductile to a brittle type of surface failure (see Fig. 6), as seen in fairly ductile steels at reduced temperatures [14]. Apparently, the crack propagated in an unstable fashion through the $\mathrm{Ag}_{2} \mathrm{Hg}_{3}$ phase $\left(\gamma_{1}\right)$ and $\mathrm{Sn}_{7} \mathrm{Hg}$ $\left(\gamma_{2}\right)$ phase around the stronger unreacted $\mathrm{Ag}_{3} \mathrm{Sn}$ phase $(\gamma)$ [11]; however, if the crack is arrested by a plastic zone, there is an even greater tendency for the crack to avoid the stronger phase as shown in Fig. 7.

Single-pass wear studies on amalgam indicated that material $\mathrm{A}$ has better wear characteristics than
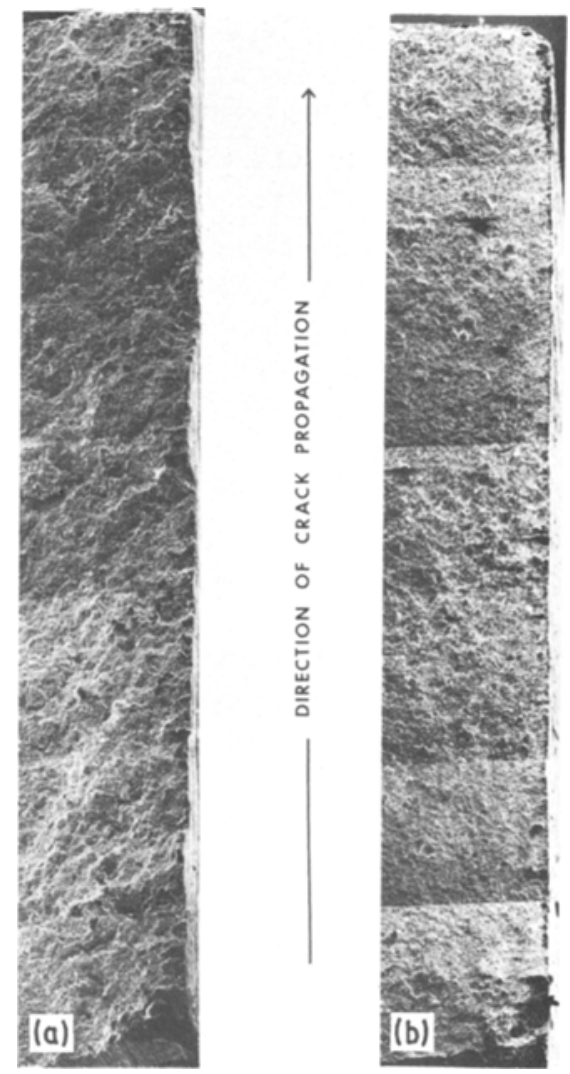

Figure 6 Scanning electron photomicrograph of fracture surface of (a) material $B$, and (b) material $C$, from notch tip to end of fracture surface at a loading rate of $0.005 \mathrm{~cm} \mathrm{~min}^{-1}$. The arrow indicates the direction of crack propagation.

materials $\mathrm{B}$ or $\mathrm{C}[5]$. The fracture toughness data indicate that there is a difference between the fracture toughness of material $A$ and materials $B$ and $C$. Therefore, a relationship appears to exist between single-pass wear studies and fracture toughness testing of amalgam.

\section{Conclusions}

The fracture toughness and critical strain energy release rate, which measure the resistance to unstable crack propagation, were determined for an admixed, a lathe-cut, a spherical, and two atomized high-copper dental amalgams. At a loading rate of $0.005 \mathrm{~cm} \mathrm{~min}^{-1}$, the spherical amalgam had the highest resistance to unstable crack propagation. The lathe-cut amalgam had the highest resistance to unstable crack propagation at the higher loading rate of $0.05 \mathrm{~cm} \mathrm{~min}^{-1}$ in both 24-hour and one-month tests. Under all test 

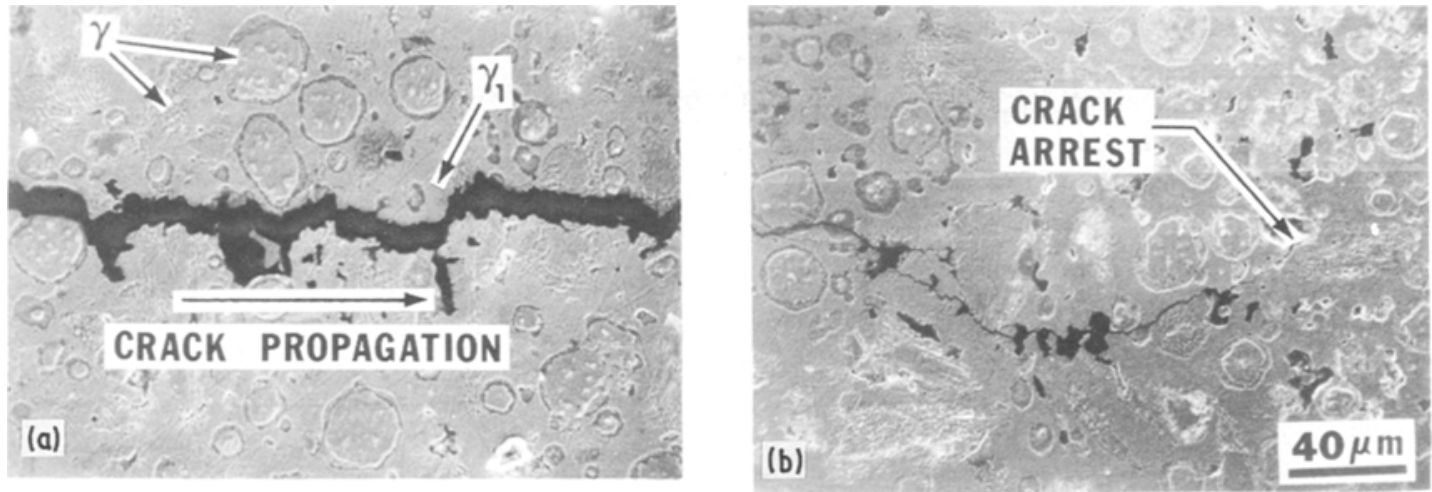

Figure 7 Scanning electron photomicrograph of (a) unstable and (b) arrested crack in material A at a loading rate of $0.005 \mathrm{~cm} \mathrm{~min}^{-1}$.

conditions, the atomized high-copper amalgam with the highest copper content and lowest silver content had the lowest resistance to unstable crack propagation. The fracture toughness data were consistent with results obtained in single-pass wear studies of amalgam.

\section{References}

1. G. R. IRWIN, Int. Appl. Mech. 24 (1957) 361.

2. A. A. GRIfFITH, Phil. Trans. Roy. Soc. London A221 (1920) 163.

3. C. GURNEY and Y. W. MAI, Eng, Fract. Mech. 4 (1972) 853 .

4. J. C. ROBERTS, J. M. POWERS and R. G. CRAIG, J. Dental Res. 56 (1977) 748.

5. Idem, J. Biomed. Mater. Res. 11 (1977) 513.

6. A. G. ATKINS, Private communication (1974).

7. W. F. BROWN Jr. and J. E. SRAWLEY, "Plane Strain Crack Toughness Testing of High Strength Metallic Materials", ASTM STP No. 410 (ASTM, Philadelphia, 1966) p. 13.

8. J. F. KNOTT, "Fundamentals of Fracture Mechanics," (John Wiley, New York, 1973) p. 108.
9. University of Michigan, Statistical Research Laboratory, "A Manual of Elementary Statistics Using MIDAS”, (Statistical Research Laboratory, Ann Arbor, 1975) p. 301.

10. P. L. OGLESBY, G. DICKSON, M. C. RODRIGUEZ, R. M. DAVENPORT and W. T. SWEENEY, J. Res. Nat. Bur. Stand. 72 (1968) 203.

11. O. YOUNIS, K. ASGAR and J. M. POWERS, $J$. Dental Res. 54 (1975) 1133.

12. R. G. CRAIG and F, A. PEYTON, editors, "Restorative Dental Materials", 5th edition (C. V. Mosby, St. Louis, 1975) p. 185.

13. J. M. POWERS and J. W. FARAH, J. Dental Res. 54 (1975) 902.

14. N. H. POLAKOWSKI and E. J. RIPLING, editors, "Strength and Structure of Engineering Materials", 1st edition (Prentice-Hall Inc., Englewood Cliffs, New Jersey, 1966) p. 394.

Received 10 May and accepted 9 September 1977. 